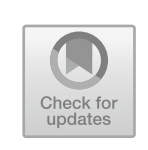

\title{
Learning Fiction by Subscription: The Art and Business of Literary Advice 1884-1895
}

\author{
John S. Caughey
}

\section{INTRODUCTION}

In the last decades of the nineteenth century, fiction-to adapt a phrase of Edward Gibbon-was elevated into an art and degraded into a trade. Beginning in the mid-1880s, an agitated coupling of craft and commerce in the Anglo-American world of letters created a circle either virtuous and vicious - depending on one's literary sensibilities - making authorship available and attractive on an unprecedented scale. It took literary studies until the middle of the next century to awaken to fiction's standing as an art, and the discipline's reckoning with its commercial aspects was delayed further still. Fiction's arrival as a legitimate player on the cultural field had, however, occasioned an earlier era of discussion and dispute in the literary advice industry, where virtually every aspect of writer's life came under consideration. According to the tenor of the times, the writer of fiction, unlike the poet, could be made, or rather self-made. Such making, however, occurred neither at the foot of a professor nor in a fit of Romantic agony off in a garret somewhere, but rather by subscription.

\section{J. S. Caughey $(\bowtie)$}

University of California Los Angeles, Geffen Academy, Los Angeles, CA, USA

(C) The Author(s) 2021

A. Masschelein and D. de Geest (eds.), Writing Manuals

for the Masses, New Directions in Book History,

https://doi.org/10.1007/978-3-030-53614-5_2 
In the informal school of the late-Victorian periodical market, articles on technique expounded fundamental principles, authors debated the merits of typewriters, advertisements from agents interrupted the progress of a serial, illustrated "at-home" intimate interviews lingered over the material fruits of the literary laborer's life, and cash-prize story contests invited the readers to try their own hand. At the heart of it all was the short story, a self-consciously new genre uniquely available as an "art" that could be practiced-with profit-by anyone.

The abrupt rise of literary advice discourse-a formation that would quickly expand beyond the magazines to include how-to handbooks, correspondence schools, literary consultation services, and other related practices-struck writers and critics of the time with considerable force, spurring a welter of arguments over its value. Many embraced it enthusiastically, lauding it as a democratizing force that opened literature to women and the working classes. Many others rejected it with an equal measure of vehemence, seeing in it the very end of literary history. Critics today, however, are apt to be struck with considerably less power and tend to overlook it altogether. If they acknowledge it all, it is to dismiss this proliferation of literary meta-discourse as little other than a symptomatic by-product of more fundamental social or economic forces, one of the intermediary modes through which capitalism coaxes individuals into ever-deepening acts of self-commodification. Indeed, literary advice seems a particularly insidious activation of capital in which individuals are invited to treat themselves as the raw material, mining their deepest personal experiences and most meaningful relationships in the hopes of turning out a saleable story. Unsurprisingly, if it appears in scholarly studies at all, literary advice thus usually features as the uninspiring background against which the protagonists of literary history define themselves, offering them simple formulae to be defied, economic imperatives to be negotiated, and conventional wisdom to be subverted.

To dismiss the field of literary advice in this way, however, is not only to overlook one of the most prominent and definitively novel features of the period but it is also to turn away from an open window on an aspect of creative practice that is too little studied. Literary scholars often regard the literary advice proffered in the late nineteenth century as simplistic, naïve, and vulgar because they treat it as if it were a kind of proto-novel theory. But literary advice discourse was not about how to interpret fictions but about how to make them-and make a living from them. The form of knowledge that the field promulgates is different in kind from "theories" 
of fiction, and to think of it as primarily ideological is to misunderstand it altogether. The practical focus that literary advice discourse takes on the writing process, from inspiration to composition to publication, connects the content of a fiction with forms of life that produced it, and links professional life with representations of life. The vantage point offered through literary advice discourse proves particularly useful because of its scale, a scale that opens the field of vision out beyond the tactics of an individual author, capturing rather a field of social interactions and practices both commercial and artistic. The literary advice industry, in short, was both a market and a marketplace of ideas.

In order to help keep this distinctive character of the field in mind, and for the sake of terminological convenience, I will employ the term "fictioneering" to refer to the specific form of literary do-it-yourself fashioning that emerges in the final fifteen years of the nineteenth century. In practice, the term was only used sporadically-and often derisivelybut it has the advantage of signaling the self-consciously middle-ground position that literary advice discourse stakes between theory and practice and between art and business. Looking to the profession of "engineering," fictioneering thinks of itself a fusion of science and art that employs specialized knowledge and skills for applied, often explicitly commercial, ends. A fictioneer anxiously aspires to be "professional," desiring legitimacy in the eyes of the broader public while nonetheless wanting exemption from the gatekeepers, fixed routines, and bureaucratic demands of the more established professions. Advice articles, handbooks, novels, and stories about artists - the whole collective enterprise of fictioneering-had concrete implications for who the writer aspired to be, for what she took her subject to be, for how she would give it form, and for how she would live, in both the social and the economic sense of that term. To become a literary worker was not only to pursue a newly professionalizing career, but also to craft a self. At first sight, the archive of fictioneering merely records, in the most prosaic way possible, the ways in which a writer might make herself through prose: the various exercises, technical tips, and recommended model readings that anyone who aspires to write fiction needs to work through. Yet, within these atlases of the mundane lurks a stranger and deeper patterning of life as well as a possibility for rethinking the nature of literary knowledge.

Without question, there is much within the articles and advice columns that seem grossly commercial, embarrassingly sincere, or flat-out ridiculous; the genre is undeniably the haunt of small-time grifters and 
enthusiastic quacks. Because of the mechanistic associations and taints of middlebrow aspiration, writers who may well have benefited from how-to literature are generally disinclined to admit it. On top of that, much of the advice might, in retrospect, appear as bad advice. The present study can only admit to finding in all of these apparent deterrents additional recommendations to the subject, as they testify to a literary culture that is very much in flux and, therefore, very much alive. In such a culture, competing practices for solving the deepest problems involved in both telling and selling a work of art appear in the open, where they figure as the central issues any aspirant to fiction would be forced to deal with. The would-be writer had to study the market, experiment with it, and shape a self in relation to it. The practical knowledge a fictioneer gained regarding the field of literary production might be wrong - she could entirely misjudge both what was wanted and what she was capable of providing-but such failures ought to figure into literary history as much as the triumphs, given how much the former outnumber the latter.

In what follows, I focus on the "long decade" of fictioneering's emergence, which begins in 1884 with the landmark "Art of Fiction" debate and ends in 1895, a year that marks a shift in literary advice discourse with the opening of "the age of the handbook" when the stand-alone how-to manual took over as fictioneering's primary vehicle. ${ }^{1}$ Between these years, literary advice discourse most actively unfolds within the relatively contained space of periodical culture. Because it is the focus of another chapter in this volume, my treatment of the "Art of Fiction" debate is necessarily glancing (see Atwell in this book). The brief detour through this seminal moment is meant only to show how the exchange opened-rather than ended-an intense "era of discussion" while also demonstrating the role that periodical culture played in sustaining it. A broad and generally chronological outline of the periodical landscape follows, charting the ways in which magazines progressively realize their interactive potential, most intensely with the genre of the short story. I conclude with a case study on a "school of fiction" run by Atalanta magazine that is intended to display the characteristic elements of fictioneering in a more fine-grained way while also calling particular attention to the way it opened education in fiction to new classes of writers. The point throughout is to make visible an interactive literary culture that does far more than impose itself on unwitting consumers. While it is shot through with commercial interests, literary advice discourse is not a deterministic and dominating ideological formation. What it does instead is provide 
an array of practices and ideas that individuals put to use on their own terms. Rather than reducing literature to disposable commodities that feature pre-digested plots, the interactions engendered within magazines produced a constellation of competing ideas and ideals, including the very distinction between authentic literature and mere market fiction.

\section{The Art of Discussing Fiction}

Looking at the literary field between 1884 and 1895 from the angle of the fictioneer is to glimpse a universe parallel to the one usually offered in literary histories. In this alternate world, familiar names appear in diminished roles and unexpected capacities while unknown figures loom forth, rivaling the artists we now take to define the period. In both worlds, the "Art of Fiction" debate of 1884 stands as a landmark. In literary studies, Henry James's contribution is the lone surviving document. James emerges as the undisputed winner and his endlessly anthologized essay has been called the "most popular and surely the most influential brief statement of fictional theory ever made" (Miller 1972, p. 27). Indeed, one of the long-standing questions about the debate is why James chose for his primary antagonist an "efficient $[. .$.$] hack"$ like Walter Besant and why he chose to publish his essay in the middlebrow Longman's magazine (Edel 1962, p. 124). Literary historians have often made their perspective on the debate out to be the contemporary consensus as well, but the view at the time was quite different. Our view of James's influence depends on making the "Art of Fiction" debate into a dispute over how to interpret fiction rather than about how to write it. Perhaps the most efficient way to recalibrate our understanding of the moment is to remember that in 1895 , more than a decade after the original exchange, James endured the profound shame of the Guy Domville debacle while Walter Besant, by contrast, earned the rare distinction of a knighthood for his service to the world of letters. At the very least, the contrast between Sir Walter's elevation and Mr. James's humiliation provides a suggestive clue of how differently the literary field can be viewed, and the first step toward understanding this other view is to return to the larger context of the debate, a context that is surprisingly well preserved in the periodical press.

While the "Art of Fiction" affair began with a lecture that Besant delivered before the Royal Institution on April 25, 1884, the initial rise of fictioneering plays out almost entirely in periodical culture. If 
"modernism began in the magazines"-as Robert Scholes and Clifford Wulfman claim - so too did fictioneering. Indeed, they often coexisted in the same issues (Scholes and Wulfman 2010, p. 43). ${ }^{2}$ Besant's lecture, in fact, owed its immediate preservation and its lasting impact to the newspaper and periodical press. Within a few weeks of the talk, the Times offered a leading article on the occasion and the Pall Mall Gazette offered two-a short notice and a more substantial piece by the Scottish man of letters Andrew Lang, yet again titled the "Art of Fiction." The interest thus generated in the event led Chatto \& Windus to publish the lecture in pamphlet form with a new appendix by Besant on, fittingly enough, how to publish. Henry James, who did not attend the lecture, worked from this text to compose his response. Before Longman's published James's article, however, Besant's sally spurred further comment from The Spectator and a number of other journals in Britain as well as the Nation, the New York Times, and the New York Tribune in the United States.

Contrary to the usual scholarly narrative, James's essay, published in September 1884, did not put a definitive stop to this burgeoning discussion, but rather brought in new voices, just, it seems, as he suspected it would. One of the more important further contributors was Robert Louis Stevenson, whose "A Humble Remonstrance" directly argues back against James. Also published in Longman's, Stevenson's essay forcibly returns the discussion to the practice of writing. "Mr. James," Stevenson observes,

spoke of the finished picture and its worth when done; I, of the brushes, the palette, and the north light. He uttered his views in the tone and for the ear of good society; I, with the emphasis and technicalities of the obtrusive student. But the point, I may reply, is not merely to amuse the public, but to offer helpful advice to the young writer. And the young will not so much be helped by genial pictures of what an art may aspire to at its highest, as by a true idea of what it must be on the lowest terms. (Stevenson 1884, pp. 146-147)

The force of Besant's lecture, as Stevenson recognizes more clearly than even Besant himself did, is that it opens a space for talking about literature as a form of practice rather than as a "finished picture." James himself took the rebuke as both serious and substantial, making significant revisions to "The Art of Fiction" on its basis. ${ }^{3}$ In a letter thanking Stevenson for his criticisms, James wrote that the ideas in his essay "were only half 
of what I had to say, and some day I shall try and express the remainder" (James quoted in Smith 1948, pp. 102-103).

If James was not half-done with what he had to say, neither was anyone else, and the discussion initiated in the debate grew rapidly in scope, progressing both by way of ramification and repetition. The original pieces by Besant, James, and Stevenson were reprinted in magazines, pamphlets, and even pirated books that bound together the contributions in a single volume while also testifying to the hunger for the information offered. But contrary to the current practice in which James's essay is published as a stand-alone piece, the various essays often featured alongside one another as evidence of a new way of talking about fiction as a practical art and the weight given to the various entries figured differently than it does at present. ${ }^{4}$ In an appendix on "Further Reading," the 1901 handbook How to Write a Novel, for instance, puts Besant's essay at the head of list, while James's article comes tenth and Stevenson's twenty-third. A similar perspective appears in Brander Matthews's seminal "The Philosophy of the Short Story" (1885), a work contemporary with "The Art of Fiction" debate, and also first published in the magazines. Initially featured in the October issue of Lippincott's, Matthews's essay "eavesdrops" on that controversy, from an adjacent column, as it were:

If it chance that artists fall to talking about their art, it is the critic's place to listen, that he may pick up a little knowledge. Of late, certain of the novelists of Great Britain and the United States have been discussing the principles and practice of the art of writing stories. Mr. Howells declared his warm appreciation of Mr. Henry James's novels; Mr. Stevenson made public a delightful plea for Romance; Mr. Besant lectured gracefully on the Art of Fiction; and Mr. James modestly presented his views by way of supplement and criticism. (Matthews 1885, p. 366)

Matthews's remarks usefully map the field of the debate from a contemporary perspective, putting British and American novelists in dialog and giving such different relative weights to the disputants that James's essay becomes a "supplement." It also crucially emphasizes that the discussion consisted of artist's shoptalk, but noted how the extension such a topic was capable of achieving: "The discussion took a wide range. With more or less fullness it covered the proper aim and intent of the novelist, his material and his methods, his success, his rewards, social and pecuniary, and the morality of his work and of his art" (ibid.). The central point 
about this discussion, however, is that its audience was meant to do much more than listen. The most eager auditors were not critics looking to pick up a little knowledge, but aspirant writers looking to learn practical skills. Treating the literary market, to which it was so recent an addition, as a newly discovered world whose riches were open to the enterprising, fictioneering promised at once to map this complex and treacherous terrain and to make their readers an important part of it.

Fictioneers guided their charges by teaching them craftiness as much as craft, sometimes bringing home their lessons at the expense of less wary. Whatever their scruples, fictioneers cultivated a highly self-conscious attitude toward the market and adopted an attitude toward the information communicated by the newspapers and magazines that little resembles the figure of Walter Benjamin's anxious modern whose "imagination" has been "paralyzed" by the newspapers (Benjamin 1969, p. 159). The practical orientation toward the news is most evident in the specialty periodical $s$ devoted to literary laborers that spring up on both sides of the Atlantic in the years immediately following the "Art of Fiction" debate. Taking the shoptalk of the writer to a vastly more detailed level, these magazines urged a very different relationship to the "information" of the nascent "information age," teaching their readers to turn the space of the news media into a training arena. The stories offered in the newspapers and magazines were to be studied, imitated, cut into clips, and sorted in plot files; they were the places one submitted one's own work and if the editors proved unresponsive or unscrupulous, one could find out how to deal with them too.

This interactive focus worked to create a generative cycle that marked a palpable break in literary practice. As James noted in his essay, "within [the last] year or two" "the era of discussion would appear to have been to a certain extent opened" (James 1884, p. 502). ${ }^{5}$ James's view of the discussion shows a prescient awareness of how theorizing about how to write fiction had become almost as absorbing as fiction itself. James in fact brings the discussion of how to write novels before the sole "obligation" he's willing to demand of a novel — that "it be interesting" — and finds that it satisfies that demand. ${ }^{6}$ Indeed, the opening line of his essay justifies its "comprehensive" title by reference to the "interesting pamphlet lately published under this name ["The Art of Fiction" by Mr. Walter Besant." The reaction to Besant's pamphlet "appears to indicate that many persons are interested in the art of fiction" (ibid., p. 502; emphasis added). 
Other laborers in the same field will give it the light of their experience, and the effect will surely be to make our interest in the novel a little more what it had for some time threatened to be - a serious, active, inquiring interest, under protection of which this delightful study may, in moments of confidence, venture to say a little more what it thinks of itself. (ibid., p. 503; emphasis added)

If fiction is an art, then paying attention to the state of the art, the leading edge of technique, becomes part of the art. The reflexive representation of this interest-the "venture to say a little more of what it thinks of itself" - is tied up with both attention and mode of expression. In short, writing about writing becomes a form of essential experience for the novelist and an essential way of making fiction into more of an art. Such a view suggests that even when it came to his theories, James was far less aloof than he has long been taken to be. Closely attuned to the burgeoning interest in fiction though he was, James must still have been surprised at just how many laborers were soon to offer up the light of their experience.

The "era of discussion" took a step forward in 1887 with the launch of The Writer in Boston by the intrepid William H. Hills. Subtitled "A Monthly Magazine to Interest and Help All Literary Workers," The Writer closely echoes the key terms of James's "The Art of Fiction." So interesting did literary workers find Hills's magazine that he soon followed it up with a sister periodical called The Author in 1889. In 1891 Besant edged into the game and began "conducting" a periodical also called The Author to serve the "organ" for the Society of Authors. The mid1890s saw The Editor (New York: "The journal of information for literary workers"), The Writers' and Artists' Year-Book (London), and Bookman, which introduced best-seller lists to the world in 1895 .

Conveying practical advice submerged in the rhythms of working life, these magazines depended on scattered contributors who wrote in from afar. A periodical such as The Author not only provided professional advice, but it conferred its own title on the hopeful aspirant who had something to say. One could thus first become an author by writing for The Author. Such modes of compilation produced interestingly diverse results. The Boston-based Writer, for example, featured all of the following between its covers: lead articles on writing fiction, short stories, "Gossip on Authors," "Queries," "Book Reviews" of literary 
texts, notices of useful articles in other magazines, and "Helpful Hints and Suggestions." Here is how the magazine describes what it is looking for:

Readers of THE WRITER are urged to tell for the benefit of other readers what little schemes thay [sic] may have devised or used to make their own work easier or better. By a free exchange of personal experiences every one will be helped, and, no matter how simple a useful idea is, it is an advantage that every one should know about it. (Hills 1889, p. 233)

The schemes of the magazines' readers covered an astonishing array of topics, with nothing too minor to escape notice. Debates raged over the typewriter in particular, whether it was better to invest in buying one and learning to use it, or whether it was wiser to outsource the work. Contributors weighed in on the benefits and drawback of various models and often proposed modifications for the machines such as a "cheap arrangement" for "persons who prefer the type-writer knee-shift at the right" (B.T. 1888, p. 71). Filing systems were likewise much discussed, testifying to the various attempts to manage the deluge of information and turn it to profitable account. Philip G. Hubert, who admitted to collecting "twentyfive thousand newspaper articles and perhaps five thousand magazine articles" over the course of a decade, discussed his "various methods of keeping and filing away for reference" such a colossal bundle of material in "The Filing of Clippings" (Hubert 1888, p. 163). The hazards of the occupation both minor-sleeplessness, writer's cramp, and methods for removing ink from clothing (clear spirit of camphor does the trick)and major-libel and copyright infringement-were regularly addressed. Even the magazine's ads, featuring typewriters, shorthand instruction, and other services for literary workers fell under the general mission of the magazine. As Hills, the editor and publisher of the journal, put it, "Readers of The Writer who skip the advertising pages do not get the full value of the magazine" (Hills 1889, p. 228).

Individually, the various tools and tricks of the trade may seem insignificant enough, but taken together, they represent a marked shift in the art of writing. An April 1888 article on "Method Needed in Literary Work" by A. L. Hanscom testifies to the profession's emerging practical philosophy. "It is no longer necessary," Hanscom observes, "for a literary man to wear long hair, roll open his shirt collar like Byron, or have the delirium tremens with undoubted regularity" (Hanscom 1888, p. 84). What is 
necessary is an undoubted regularity of a different sort, namely a practical method for managing both oneself and one's work that was founded on the solid base of practical knowledge. This knowledge, however, was the possession not of the individual writing alone in a garret surround by half-empty bottles, but of the community of writers at large, a community linked by the magazines.

Besant's The Author renders this communal, guild-like aspect with particular clarity, and adds a new dimension to the key term "interest." The Society, founded on the idea that knowledge of the profession could effectively be circulated through face-to-face social interaction, had found itself in need of a new principle of association. The original plan "to hold frequent meetings for the purpose of conference and discussion" had come up against the fact that "a large number of our members live in the country" and so "we could seldom hope to obtain a really representative gathering, and the discussions would have the tendency to drop into the hands of a few, and still be robbed of half their value" (Besant 1890 , p. 1). Even if large, representative gatherings had been possible, the Society further realized that discussions would be of little value if those taking part in them were not already informed: "no discussions can have any real value which are not founded on knowledge of the facts. Now, the ordinary member knows little of the facts." What was needed was both a space for discussion and an avenue for the circulation of knowledge.

The Author is therefore founded to be the organ of literary men and women of all kinds - the one paper which will fully review, discuss, and ventilate all questions connected with the profession of literature in all its branches. It will be the medium by which the Committee of our Society will inform its members generally of their doings, and it will become a public record of transactions conducted in the interests of literature, which have hitherto been secret, lost, and hidden for the want of such an organ. (ibid.)

Besant's use of the word "interest" in the foregoing adds an additional layer to James's key term, supplementing the aesthetic stimulation of curiosity with concrete material stakes. The turn is often seen to be a vulgar one, but it is worth remembering that Besant's abiding concern in defending the property rights of authors was in protecting the most vulnerable members of the guild from the publishers who regularly exploited them. 
Broad though it be, the interesting discussions that the expanding "guild" of writers carried on through the periodical press represents only part of the story. The other part was the story, or rather the short story, itself. More than just "organs" for information or venues for critical exchange, magazines offered the ideal training ground for the would-be author as well as a potential means for sustenance. The short story served as the ideal vehicle for uncovering the principles behind making both art and artists. To see how it functioned in this way, however, it is necessary to work against a set of entrenched oppositions that fragment the development of the art form. In this, the story of the short story has seemed to take on the formal character of its object of study, and while there is not space here to tell the tale in full, some progress can be made toward collecting the pieces.

\section{The Story of THE SHORT StORY}

The oldest divide when it comes to the short story is a national one. American literary historians have claimed the short story as a genre that was distinctly theirs, tracing it back to Irving, Hawthorne, Melville, and (especially) Poe. Its development, its theorization, and even its commercial viability are taken to long precede the arrival of fictioneering. Whatever dramatic increase the close of the nineteenth century saw in the production of short stories can simply be attributed to the increased demand for a preexisting product brought on by the magazines. The craze for short stories was, on this view, simply an intensification of hunger for an already well-defined genre. From other angles, however, a different, if somewhat overlapping, binary takes hold between the short story as mass-market commodity and modernist art. Here, the literary short story is considered the modernist genre "par excellence," and insofar as it rises to an art, it does so at the hands of James Joyce, Katherine Mansfield, Virginia Woolf, Ernest Hemingway, and their continental predecessors. ${ }^{7}$ Other writers have received critical attention, but only in so far as they exhibited proto-modernist, and anti-commercial, tendencies. Dominic Head, for instance, argues "the short story shows itself, through its formal capacities, to be a quintessentially modernist form" (Head 1992, p. xi). In Adrian Hunter's view, "In many respects modernism has been, and remains, the short story's centre of gravity-and not only in academic criticism" (Hunter 2007, p. 4). Modernist "innovations," Hunter continues, "most notably the 'epiphany,' have assumed the status of first principles 
for aspiring writers of short fiction, not to mention the professionals who teach them on creative writing courses throughout the English-speaking world" (ibid.). ${ }^{8}$

Contrary to these abiding ideas, a more continuous development of the short story comes into focus when the genre is connected to the discussion initiated in the "Art of Fiction" debate and carried on afterward with considerable vigor in the magazine culture. Long before the epiphany had come to assume its lofty position, fictioneers had carefully elaborated other first principles and uncovered a trove of "secrets" about the form, and they did so in venues that strongly link the British tradition of the short story with the American one, making for a phenomenon that spans the Atlantic. Importantly, what was elaborated was not merely theoretical but rather a comprehensive practical poetics based on experiment and experience. The direct connection between the short story and the "Art of Fiction" debate is easily overlooked if only Henry James's point of view is the only one represented, but it comes into ready focus if the discussion is followed just a step further. Brander Matthews, whom we have already seen eavesdropping on the "Art of Fiction" debate, had his own contribution to make to it when he noted that, "with all its extension, the discussion did not include one important branch of the art of fiction: it did not consider at all the minor art of the Short-story" (Matthews 1885 , p. 366). Following up on this oversight, Matthews added, "it has seemed to the present writer that there is now an excellent opportunity to venture a few remarks, slight and incomplete as they must needs be, on the philosophy of the Short-story" (ibid.). Having seen his opening, Matthews would make the most of the opportunity, and the short story would become more than a minor art.

A key member of the generation of literary scholars who pushed back against the philological model of research, Matthews championed the short story in an eclectic body of work. Although primarily an academic, serving as a professor of literature, and later of drama, at Columbia, he did make some notable experiments of his own in short fiction. While Matthews's own literary output was slight, he was friendly with many better-known writers including Besant, eventually going on to work with him to promote the 1891 copyright agreement between England and the United States. Matthews also later put together an early anthology (1907) of short fiction similar to the classroom texts that would come to prominence in the middle of the twentieth century. 
Matthews's most important work by far, however, was "The Philosophy of the Short-story" which introduced (or re-introduced) some of the key terms that fictioneering would take up as it turned to the short story. He borrowed much of it from Poe; even the title of directly echoes "The Philosophy of Composition" (1846). Matthews, however, did not simply rehash Poe; he virtually resurrected him within the Englishspeaking world, elevating him as to nothing short of the "patron saint of the short story" and belatedly validating his vision of short fiction as the supreme modern literary art form, one both lucrative and aesthetically rigorous (Levy 1993, p. 10). Until "The Philosophy of the Short-story," few in the English-speaking world paid attention to Poe or his theories." The author and scholar Fred Lewis Pattee, with only slight exaggeration, attempted to correct the record early on, arguing that

Poe's influence had been almost nothing. There is no evidence in all the critical writings of the mid-century or in any of the literary correspondence of the time that a single reader in 1842 had seen his review of Hawthorne or that anyone could profit at all from the brilliant technique of his Tales of the Grotesque and Arabesque. For a generation after his death his tales were mentioned only as terror-compelling things, strange exotics standing gruesomely alone and almost to be regretted among the conventional creations of American literature. (Pattee 1923, p. 145)

Pattee's claims are born out at the economic as well as at the aesthetic level. As Dean Baldwin demonstrates, "it is chiefly in retrospect that the American short story appears healthy." The genre "rose and fell fitfully with the economics of publishing," emerging in "the 1830s when the flood of imports drowned the American novel ..., but it subsided when the importers and reprinters foundered" (Baldwin 2013, p. 8). Only in the 1880s were the economics of publishing, the availability of an eager public, and the interests of writers suitably aligned for experiments in fiction to flourish, and such a confluence obtained in both Britain and America.

Ironically, in his brief history of the form that so elevated Poe, Matthews would largely erase himself from literary history. Nonetheless, Matthews was instrumental in establishing the short story as genre unto itself and is the crucial hinge between British and American traditions. Something of a story about stories, "The Philosophy of the Short-story" 
was a tale often repeated. As is the case with both Besant and James, who would both revise and republish their respective "Art of Fiction" pieces, Matthews revisited his essay several times over. He first published a briefand anonymous-sketch in the Saturday Review (London) in 1884, before bringing out an expanded edition in 1885 in Lippincott's. He then included it in an essay collection from 1888 before finally publishing it as a stand-alone volume featuring a new preface and an appendix that included excerpts from Poe's critical writings in 1901. Its most lasting influence was to make writing the short story a more self-conscious endeavor. It was the ideal genre for the aspirant who was learning how to write fiction because "its brevity makes its composition simpler for the 'prentice hand" (Matthews 1885, p. 371). "Though the Short-stories of the beginner may not be good," Matthews continues, "yet in the writing of Short-stories he shall learn how to tell a story, he shall discover by experience the elements of the art of fiction more readily and, above all, more quickly than if he had begun on a long and exhausting novel" (ibid.). Matthews's concern with the process of writing is perhaps even more evident in the way he applies Poe's “The Philosophy of Composition" to fiction. The few scholars who take Matthews at all seriously make virtually no mention of the fact that Poe's essay is an account of writing poetry, one that attempts to render the process as a highly ordered one subject to conscious intervention. "The Philosophy of Composition" was a direct rebuke, after all, of "writers - poets in especial - [who] prefer having it understood that they compose by a species of fine frenzy." The central thrust of Poe's essay is to "detail, step by step, the processes by which" his poem "The Raven" "attained its ultimate point of completion" and to "render it manifest that no one point in its composition is referrible [sic] either to accident or to intuition" (Poe 2004, pp. 676-677). It is notable in itself simply that Matthews brings prose fiction under the same kind of attention given to poetry, but it is even more crucial that he suggested the short story as the point to which it could be applied. In drawing the distinction between the novel and the short story, Matthews was outlining different modes of composition; if fiction was indeed an art as Besant and James had insisted, Matthews suggests that their contention could best be realized in the short form because it requires the greatest technical exactness. The technical emphasis also drives the distinction between journalism and the short story, as Matthews was at equal pains to distinguish the true story from the "sketches" so often found in "English monthly magazines and in the Sunday editions of American newspapers" (Matthews 1885, p. 368). 
As opposed to the Short-story, which "is a high and difficult department of fiction," the "story which is short can be written by anybody who can write at all; and it may be good, bad, or indifferent, but at its best it is wholly unlike the Short story" (ibid., p. 367). The distinction between literary art and mere narrative journalism here clearly rests not so much on inherent generic qualities as on the capacities of the writer, ones best developed by the concentrated work of composition.

The gains yielded by such vigorous exercise of the prose form could later be applied to the novel, making the longer form more artistic still. "Indeed," Matthews announces, "the present excellence of the American novel is due in great measure to the Short story; for nearly every one of the American novelists whose works are now read by the whole Englishspeaking race began as a writer of Short stories." Matthews thus thought of the short story as both an end in itself and as a form of practice: "The physical strain of writing a full-sized novel is far greater than the reader can well imagine. To this strain the beginner in fiction may gradually accustom himself by the composition of Short-stories" (ibid., p. 371). The idea that the short story is a natural starting place for the aspirant writer may well seem obvious today in part because it has become the default pedagogy of creative writing programs, but Matthews's assertion of the fact represents a significant rethinking of the short story that both depends on the idea that fiction is an art and helps further realize that idea by specifying its ideal venue of training. In reviving Poe and in articulating the short story as the ideal form of artistic training, Matthews broadened the discussion of artistic process. In the wake of this particular contribution to the "Art of Fiction," the short story would go on to become, in Henry James's phrase, "an object of such almost extravagant dissertation" in the era's periodical culture (James 1898, p. 652).

If the short story had not at first been considered in the "Art of Fiction" debate, it made up for the neglect by occupying a leading role in any discussions of the art in the subsequent decade and a half. In the years after Matthews had published "The Philosophy of the Shortstory," the genre was approached from every possible angle. From its inception, William Hills's The Writer frequently featured articles on the topic. 1888 alone featured Emily Wheeler's "The Deceitful Short Story," William Perry Brown's "My Struggle with the Short Story," Virginia G. Ellard's "How to Write a Story" and A. M. Gannett's similarly titled "How to Write Short Stories," in addition to a wealth of quick tips and 
helpful hints. The first-named essay notably argued for the central importance of revision while the second highlights the difficulty of the form while conceding that "a ray of hope to sustain the young writer in his efforts" is that "in no other field of literature is success so directly a result of cultivation and determined zeal; for there is a literary mechanism about the work, which cannot be disregarded, and the secret of which can be acquired only by patient and persistent study" (Ellard 1888, p. 239). Gannett's piece, by contrast, tells a story of its own by following the progress of an anonymous "lady who is rapidly winning a name as a writer of capital short stories" be revealing her hard-won secrets of success (Gannett 1888, p. 86). Similar columns with less anonymous writers giving their trade secrets away would become a regular feature of The Writer. The most emblematic of such stories might come from Horatio Alger, who explained the principles of his success in "Writing Stories for Boys," a multi-part sequence of articles that unfolded month-by-month in 1896.

Other periodical s catering to literary workers were similarly larded with advice articles. The March 1897 American edition of The Bookman, for instance, gave Jane Barlow, Robert Barr, Harold Frederic, and Arthur Morrison each a chance to weigh in on "How to Write a Short Story." Among the contributions to periodicals of a broader audience, essays by Frederick Wedmore (Nineteenth Century, 1898), Bret Harte (Cornhill, 1899), and Henry Harland (Academy, 1897) gained enough notoriety to feature in discussions of the short story for years to come, while Lippincott's gave Frederick M. Bird the chance to take the inverse tack in his "Magazine Fiction and How Not to Write It" (1894). Poe, suddenly resurrected, featured in many discussions, and copies of his Hawthorne essay and his "The Philosophy of Composition" circulated both in extracts and full reprint. When The Critic selected the "Twelve Best American Short Stories" of all time in 1897, both "The Gold Bug" and "The Murders in the Rue Morgue" made the list. Meanwhile, short story contests for the living sprung up across Britain and America, featuring at every level, from the most provincial newspapers to the widest circulation weeklies. Magazines like The Writer and The Author were careful to bring the biggest prize contests to the attention of their readers, just as they also noted key literary articles that appeared elsewhere in the press. Then, of course, there were the stories themselves, a seemingly fair proportion of which were fictions about writing fictions. Henry James's are the most well-known now, but not the best-known then, likely in part because of 
his struggles with "compression," that central virtue of the short story. Besant seemed to offer a new collection of stories every year, several of which featured writer protagonists. Though not a short story, his longer Künstlerroman, All in a Garden Fair (1883), which was aptly dubbed an optimist's New Grub Street, gained Rudyard Kipling's everlasting gratitude for pulling him out of a period of profound depression in $1886 .^{10}$ Among the bumper crop of self-reflexive fin-de-siecle stories, Carolyn Wells's satiric "The Vivisectionist" (Lippincott's Monthly Magazine; 1896) and Vernon Lee's "Lady Tal" (1892) bear particular mention as both women offered their own contributions to the art of fiction discussion. Lee's stately "On Literary Construction" appeared in The Contemporary Review in 1895, while Wells would write what was the first full-length how-to book on mystery and detective stories in 1913 as part of J. Berg Esenwein's "How-to Write" line of handbooks. In some ways, Technique of the Mystery Story might well be considered the first work of sustained criticism in the genre, albeit from a fictioneer's perspective.

The intertwining of the short story and discourse about the short story-most notably about how to produce it-complicates the usual picture where its form, at least in its pre-modernist phase, is seen chiefly in terms of its commodification. To argue that the "single effect" form of short stories "facilitated the short story's easy consumption" ignores the very difficult efforts of composition that lie behind the commodity itself (Chan 2007, p. xi). In fact, the ease of consumption was something that the discourse of fictioneering significantly troubled. The interested reader, of which there were a great many, did not simply consume the story. Rather she read it, clipped it, filed it away, studied it, dissected it, imitated it, and then attempted to exceed it. The anonymous lady writer of "capital stories" profiled by A.M Gannett proceeded thusly:

She selected those stories in The - which are best written, using them for her models. I do not mean that she copied or imitated. Far from it; but she studied them, learning the secret of their worth, just as an artist studies a fine picture or a bit of landscape, not for reproduction, but to get the key for producing beauty himself. (Gannett 1888, p. 86)

These sample stories she kept before her, checking them again and again to see whether she was "approaching her models" (ibid.). Used in such a way, the short story, such an absolutely central feature of the 
late nineteenth-century periodical press, offers a quite different form of interaction than that of the "shocked" passive consumer.

Moving the focus of attention from finished products (stories) to the acts of production that they both required and inspired thus permits a reading that goes against the grain of scholarly work on late-Victorian and early twentieth-century periodical s focused on how the magazine marketplace commoditized fiction and dictated the poetics of the short story by way of economic imperatives. Without denying such imperatives altogether, we can nonetheless remember that periodicals and newspapers from the mid-1880s onward proved to be not only spectacular economic engines that provided a forum for fiction unprecedented in both circulation and remuneration, but they also served as a site of literary instruction and apprenticeship. The periodical press was a highly networked, selforganizing field that promised news both fictional and factual, and also provided instruction on how to make news anew by, for instance, ripping a story from headlines, running it through the lens of personal experience, shaping it according to that month's column on "single-effect stories," and submitting it to next month's contest. Advice on writing fiction circulated by both the same mode-writing-and the same avenues of publication - the periodical press-as their subject, making for a strange classroom indeed. To catch the texture of learning fiction by subscription more fully, I turn in the next section to the exemplary single case study of Atalanta one of the many "classrooms" on offer in the magazines, and one that notably aims to open its seats for the "girl" writer.

\section{Atalanta's School of Fiction}

Atalanta debuted in 1887 under the editorship of W. T. Meade as a sixpenny monthly literary magazine for girls and young women, aimed at rivaling the best content of other leading literary monthlies. ${ }^{11}$ Meade, who was herself a leading author of girl's school stories, used her credentials and connections as a writer to compile an impressive list of contributors including Christina Rossetti, Charlotte Yonge, Frances.

Hodgson Burnett, Margaret Oliphant, Robert Louis Stevenson, H. Rider Haggard, and even Walter Besant. Meade did not simply solicit established names, but rather used the venture as, in Janis Dawson's words, "a unique chance to advance women's interests in the maledominated literary marketplace" by actively seeking the talents of young women writers and publishing them alongside established, well-respected 
authors (Dawson 2013, p. 478). Meade, in other words, gathered talent as a means of cultivating it among her own readership.

Such an effort is most clearly apparent in the early contributions from Besant, who offered a two-part essay "On the Writing of Novels." While specifically addressing the target audience, Besant spends most of the first part rehearsing points he had already covered elsewhere. He does, however, notably recommend the writing of short stories as a form of practice and, anticipating Virginia Woolf, also discourses on the capital need for young women to find a space of their own to write in. Having become progressively more interested in issues of literary property, Besant concludes the first part by forcefully warning girls off paying to have their own novels published. The second part more interestingly attempts to stage the thought process of a writer who has mastered the basics. While conceding that the "practised artist" will work more instinctively, Besant stages the invention and composition of a novel from start to finish. While the focus is, as the article's title indicates, on the novel, Besant insists that his student work on "what is called a one-volume story" so that the entire process can be approached consciously, thus more effectively serving as a teaching tool (Besant 1887-1888b, p. 370). The one-volume novel, he continues, is "a story which may be told in about 60,000 words, and may be divided into about fifteen or twenty chapters - the latter for choice, because the division into short rather than long chapters is a sovereign specific for the common tendency to sprawl, and instructs, moreover, in the arrangement of the incidents" (ibid.). Having established the frame, Besant leads his students through the deliberate decisions that will need to be made at every stage in the outlining and composition, from choosing a setting, to doing research, to creating characters, to writing with style. In following the process through, Besant adds flesh to the more general principles he had previously outlined. Perhaps from the influence of short story technique, Besant's chief stylistic recommendations emphasize compression and selection:

Reserve explanations. As regards these, indeed, remember that though it may be necessary for you yourself to know all about your heroine- the history of her early childhood, her favourite puddings, and even her relations with the dentist - your readers want to know little more than that she lived and moved in certain circles.... Explanations there must be, but they may often be conveyed bit by bit, with a little dialogue, with a line here and a paragraph there, so as to inform the reader of anything 
necessary. As to dialogue, remember that your characters should reveal themselves in dialogue as much as in action. They must speak as they think, each after his own manner. It is true that in real life most people seem to speak with the same forms and fashions and formula [but] you must $[\ldots]$ in dialogue $[\ldots]$ exaggerate: your talk must be crisp, it must never drag, and above all it must not be too long. (ibid., p. 374)

In the end, Besant's article very much resembles Poe's approach in "The Philosophy of Composition," where he offers "a peep behind the scenes, at the elaborate and vacillating crudities of thought" that go into constructing an artwork. While Poe chose to do so with his own "The Raven," Besant, by contrast, takes James Payn's The Confidential Agent for his example, aiming to supply his students with a technique that they can employ on their own:

the beginner will do well to study the slower and more certain methods above indicated. Let her take other novels, and subject them to a similar analysis, first finding the central idea, and then considering how the story has been evolved, filled with characters, provided with incidents, treated dramatically, and, above all, made interesting and exciting. (ibid., p. 373)

Besant's method was not the only one on offer at Atalanta, which aimed to supply its readers with instruction in literary method in even more explicit ways.

From the first issue, the magazine featured a "Reading and Scholarship Union" in which subscribers under the age of twenty-five could compete for a variety of scholarships and prizes. ${ }^{12}$ The simplest contest revolved around "Search Passages from Literature," essentially an ancestor of passage identification exam questions, where the reading not only had to identify the source of the excerpt but also both the speaker of the lines and the context in which they occurred. Passages ranged across classic and contemporary literature; the first issue, for instance, featured excerpts from Chaucer and Milton but also from Austin Dobson. More involved were the "Reply Papers." Here, readers wrote short, follow-up essays to the professional piece of criticism that featured in the issue. For the first issue, readers were to reply to Andrew Lang's piece on Sir Walter Scott, to read Guy Mannering as a follow-up, and then to respond by answering either of the two following questions:

I. What seems to you to have been Scott's Ideal of a Prose Romance? 


\section{Discuss the Plot of Guy Mannering.}

Instructions further stipulated, "Readers are free to select for answer either of the above questions, or to answer them both. But their Papers must not exceed in any case 500 words. Quality, not quantity, will be the test of excellence" (Scholarship Competition Questions 1887-1888, p. 54).

The most interesting of Atalanta's competitions, however, appeared as part of the "School of Fiction." Essentially an 1892 expansion of the Reading Union, the School offered a monthly lesson on a select aspect of fiction, accompanied by competitive creative exercises. The first installment of the school was a lesson on "Style in Fiction" by W. E. Norris. Norris notes that "The art of writing fiction has of late years been made the subject of innumerable articles by persons most, if not quite all, of whom are doubtless competent and well-informed," but he departs from what he sees as the settled dogma on the topic when he urges "the main thing" is not "to have a story to tell" but rather that the writer "should be able to tell it" (Norris 1892-1893, pp. 59-60). Norris repeatedly emphasizes the need for practice in the art of style arguing against the idea that it is an inherent possession of every person:

the beginner who essays, without preparation or apprenticeship, to tell his story in his own way will very soon discover that that is precisely what he cannot do. The words, some how, will not come; or, if they do, they come in a manner palpably and grotesquely inadequate; the sentences are clumsy, tautological, badly rounded, and jar upon the ear; the effect produced is very far from being the effect contemplated. The tyro, in short, finds out to his sorrow that writing is not in the least the same thing as talking, and that even so modest an achievement as the production of a novel is, after all, an art, the inexorable requirements of which do not greatly differ from those claimed by other arts. And, indeed, why should they? Nobody would ever dream that they did, were it not that the literary art has no schools, colleges, paid professors, no system of salutary checks to intervene between the student and his public. (ibid.)

Norris's central point is that "novels do not give pleasure or meet with acceptance simply and solely by virtue of their subject-matter" but rather from the form in which they are expressed, and which must be mastered in the same manner as the other arts. "The knack of manipulating language has to be mastered," he continues "just as that of swimming, riding, 
shooting, and playing cricket has to be mastered, and that preliminary failures are more or less a matter of course." The novelty of Norris's feature, however, is that the sorts of exercises needed to begin securing a sense of style immediately follow. The "Studies in Style" prize competition attached to the article offered three choices for a 500 -word reply paper:

A. A Dialogue between two well-known characters. (After the model of Landor's Imaginary Conversations.)

B. An Account of any Historical Incident-in the style of Macaulay.

C. Description of an Imaginary Episode; the Heroine has lost her way in a lonely tract of country, and night is approaching. Describe the situation (Studies in Composition 1892-1893, p. 63).

The winning entries paid a guinea for first and a half-guinea for second, while year-end scholarships of $£ 20$ and $£ 10$ were offered for the finest overall papers.

The School of Fiction ran in this form through the end of Atalanta's sixth volume. In the course of the year, lessons had covered "The Short Story," "The Historical Novel," "On the Art of Writing Fiction for Children," "The Novel of Manners," and more, each with its accompanying reading recommendations and composition exercises. The novel of manners "lecture," for instance, featured the suggestion "to read any of the following books: - Jane Austen's novels, Miss Edgeworth's Tales of Fashionable Life, Miss Ferrier's Marriage, Miss Burney's Evelina and Cecilia" (Studies in Composition 1892-1893, p. 135). Meade herself rounded off the course by discussing fiction "From the Editor's Standpoint," touching on the "very practical point indeed" of "how best the fiction-writer, when he has produced his work, can dispose of it" (Meade 1892-1893, p. 839). If fiction was an art, it was also a business, and there was a practical method to both. Meade offered a number of useful pointers from her behind-the-scenes perspective on how to place a work of fiction, claiming "there is no better opening for a young writer than to become a contributor to a good magazine" (ibid.). She forbade her charges from resorting "to a sort of false humility" when proposing a submission and offered the forceful commandment not to "send an article to a magazine until you have first looked through at least one of its 
numbers" (ibid., p. 840). She also recommended to "fiction-writers who are anxious to obtain magazine work" that they "turn their attention to the short complete story, and to avoid for many a day all attempts at Serial fiction" (ibid., p. 841). In lieu of the usual, follow-up exercises, the scholarship competition for the month was a sort of final exam, calling for a complete "ORIGINAL STORY" of less than 4000 words with the winner to be published in the magazine and paid at the usual rate (Scholarship Competition 1892-1893, p. 842).

\section{CONCLUSION}

A suspicious reading of fictioneering's elaboration through the periodical market is certainly possible, exposing the various exercises, instructions, and advice as so many subtle ways of coaxing an individual into deeper patterns of commodification. It would make for somewhat nervous going, considering how closely the pedagogical practices of literary studies resemble those outlined above, not to mention that fictioneering got there sooner and offered its brand of education more cheaply and more widely. A more charitable reading might find in fictioneering's undeniable-but also crucially undenied-immersion in commerce the opportunity to find an imagination not paralyzed by onslaught of the news media, but stimulated by it. This explicitly acknowledged connection between commerce and art offers a rare window of observation. Paul Delaney has, on this point, argued that "studies of authorship as a profession, and of the literary marketplace in general, have not been well integrated with what is inside the covers of books that are bought and sold - except for the inadequate idea that books simply reflect class interests" (Delaney 2002 , p. 13). By contrast, the fictioneer, having made her own study of authorship, knowingly brings these two competing impulses together in her own practice. The record of that practice, however, is best accessed not by reading it back out of the finished works, but rather by catching her at work. In openly acknowledging that writing is work, however, it is important to avoid error of turning literary labor into labor like any other. Of late, many have been tempted by the theoretical bridge that makes all art into a kind of work and adopts, or rather extends, the economically inflected material analysis that has generally governed approaches to mercantile side of literary activity. Scholars charting the emergence of the mass market for fiction at the end of the nineteenth century, in which 
fictioneering features so prominently, have long resorted to the explanatory models borrowed from economics and the work of Pierre Bourdieu has stimulated a reawakening of such approaches. Assuming "certain basic continuities between economic behavior" and the behavior of artists and other "players on the fields of culture," scholars have followed Bourdieu in extending economic calculation well beyond the monetary realm (English 2008, p. 4). Such calculation comes to include "all the goods, material and symbolic, without distinction, that present themselves as rare and worthy of being sought after in a particular formation" (Bourdieu 1977, p. 178).

In one such study of the late nineteenth-century periodical market, Winnie Chan argues in The Economy of the Short Story that the market itself "developed the modern short story genre" because it "compelled writers to play by its rules," which, however mutable they may appear to be, were nonetheless "governed by multiplying communities of taste" (Chan 2007, pp. xxiii, 4). The periodicals in the market work as both agents that "construct" such communities and as "sensitive seismographs of taste" that register the precise demands of the various readerships, thus creating the very effects that they so sensitively gauge. Whether such an argument simply illustrates its own assumed theoretical apparatus is less the point than the way in which such an approach entirely empties the work of writing - and more importantly of learning to write-of its specificity and installs instead a model of perfectly rational, but essentially unconscious, rule following in its place. Learning to write means simply acclimating oneself to the demands of one or the other of the periodicals so as to maximize one's utility. In the case of mass-market writers, they simply acquire a "market understanding of literature of literary production. $" 13$

To approach literary production by way of cultural economics, however, is to fix in advance the ontology of the mass marketplace, committing ourselves ahead of time to the idea that it is populated by individual actors who make rational-if intentionless - choices in the making, buying, and selling of fiction and literature, often without knowing that they are doing so. It little matters what an individual knows or believes they know about the marketplace, much less about "art"; in fact, the system works more cleanly by discounting any knowledge that the agent might claim to hold and suggesting as Bourdieu does, that practical mastery works on preconscious, bodily level. Those that possess this so-called a "market understanding of literature" actually understand 
nothing at all, but have rather perfectly and effortlessly internalized the demands of commercial capitalism. The same goes for the high-cultural artists who have internalized not the dictates of the mass market, but those of the "loser wins" market.

Such studies treat intention, when it comes to playing the literary field, precisely the same way the New Criticism treated intention in the writing of the works. Both are simply presumed to be neither desirable nor available. In emphasizing that an individual's practical mastery of the literary field consists in a learned ignorance, Bourdieu's theory of practice entirely discounts that individual's "discourse" about her own field (and assumes, in fact, that it is misleading) (Bourdieu 1977, p. 19). Yet this move does not discount intention altogether but simply offers a substitute for it. As Walter Davis once pointed out: "The interpreter who rejects intention is forced covertly to supply an informing principle analogous to it in order to make coherent interpretation [...] possible [...] Intention is unavoidable. The only question is whether we use the artist's intention or supply one of our own" (Davis, quoted in Noël-Thomas 1992, p. 19). The intention assumed by Bourdieusian-inflected analyses generally manifests as a form of the principle of "utility maximization," in the ringing phrase of classical economics. Ironically, it is not the hack writer desperately trying to earn a living but rather the materialist literary historian who ultimately holds the "market understanding of literature," and whatever veneer of hard-headed theoretical rigor this model promises, its validity is at best unproven-and likely unverifiable. Delaney has suggested that a "model of literary culture as a dominating and relatively impersonal discursive field devalues not only the ontological objectivity of the authors, but also their economic subjectivity as it engages with the systems of literary production" (Delaney 2002, p. 6). Restoring such subjectivity by reading literary workers as if they had some sense of what they were actually up to when writing and selling their works - and could with practice, develop an increasingly better sense of what they were up to-offers an opportunity to recognize the particularity of these authors, but perhaps more significantly, also supplies the chance to rethink the available uses of literature itself from a perspective that attended so carefully to the market in order to make art. 


\section{Notes}

1. The "Age of the Handbook" is from the literary historian Fred Lewis Pattee who, in 1923 and with a deep sense of rue, saw the fictioneering handbook as the dominant feature of his own literary epoch. Pattee's The Development of the American Short Story: An Historical Survey features a very useful bibliography on "Notable Books and Articles on Short-Story History and Technique" that interestingly concludes with "1923: Fred Lewis Pattee, The Development of the American Short Story: An Historical Survey" (Pattee 1923, p. 378). For Pattee, the rise of the how-to handbook apparently marked the end of literary history, making his own work more of an elegy than a survey.

2. As Scholes and Wulfman note, even Poetry-"that ideal example of the little magazine"-had some advertising including a notable full-page ad for J. Berg Esenwein's The Art of Versification. Esenwein was the mogul of the fictioneering manual, offering a line that included nearly half a dozen how-to works on fiction in its various forms, the volume on the poetry, a how-to manual on writing for the movies, and even The Art of Public Speaking, co-authored by none other than Dale Carnegie (Scholes and Wulfmann 2010, pp. 36-37).

3 . The revised (and now standard) version appeared four years later in Partial Portraits.

4. Until quite recently, it was fairly difficult for anyone without ready access to a research library to even access Besant's essay. As David Lodge noted in his 1995 talk "Creative Writing: Can it/ Should it be Taught?": "Everybody interested in the subject knows James's essay, but not many have read the text which provoked it, for it is quite difficult to obtain" (Lodge 1996, p. 172). Within literary criticism, James's essay has long been thought to stand entirely on its own, with his brief summary of Besant's views serving as a more than sufficient explanation.

5. For reasons that will become clear, I quote from James's original version of the essay; most citations refer to revised version first published in his 1888 Partial Portraits.

6. This demand is even more emphatic in the magazine version. In the revised version, he substitutes "sincere" for "interesting" in the line toward the end of his essay that reads "But the only condition that I can think of attaching to the composition of the novel is, as I have already said, that it be interesting" (James 1884, p. 520).

7. Angeliki Spiropoulou suggests that the short story genre is "often considered the modernist form par excellence due to its constitutional fragmentariness and elasticity" (Spiropoulou 2015, p. 76).

8. It is worth pointing out that "epiphany" itself only came into currency with the publication in 1944 of Stephen Hero, wherein Joyce offers his 
now-famous definition, and that it only becomes a broadly applied critical concept in the mid-1960s. While Joyce's stories were studied from early on in MFA workshops, close attention to their use of epiphanies only appears to begin in the 1970s. The critical obsession with epiphany came long after the revolution in form. Consider that in the first edition of Understanding Fiction (1943), Brooks and Warren include only "Araby" and they do so in the final catch-all chapter on "Special Problems." Far from a central principle, the epiphany was for a long time a special case.

9. Famously, and as Matthews was aware, Poe had become influential in France owing to the efforts of Baudelaire, but his effect there proved more decisive in poetry. By way of Carl Grabo's fictioneering manual on The Art of the Short Story, Poe would also exert an influence on the Portuguese-language short story, though not until the twentieth century.

10. See Dillingham (2005, p. 52) for a brief account of how Besant's novel was Kipling's "salvation."

11. On this point, see Sally Mitchell, The New Girls' Culture in England and Janis Dawson, "Not for girls alone, but for anyone who can relish really good literature": L. T. Meade, Atalanta, and the Family Literary Magazine."

12. To ensure that only subscribers competed, a coupon clipped from the magazine had to be included with each entry.

13. The phrase is Patrick Collier's, used to characterize the Illustrated London News, a periodical that traded in "literary celebrity and the notion of fiction writing as 'a job like any other,' which can be mastered through training and experience" (Collier 2011, p. 2).

\section{References}

“Atalanta.” 1889. Church Quarterly Review 27: 500-501.

Baldwin, Dean. 2013. Art and Commerce in the British Short Story 1880-1950. London: Pickering and Chatto.

B.T. 1888. Helpful Hints and Suggestions. The Writer 2 (3) (March): 71.

Benjamin, Walter. 1969. Some Motifs on Baudelaire. Illuminations, trans. Harry Zohn and ed. Hannah Arendt, 155-200. New York: Schocken Books.

Besant, Walter. 1887-1888a. On the Writing of Novels: Part One. Atalanta I: $163-167$. 375 .

- 1890. The Author. The Author 1 (1) (May 15): 1.

. 1891. The Science of Fiction. The New Review IV: 310-315.

. 1902. The Art of Fiction. London: Chatto \& Windus. 
Blackmur, R.P. 1934. Introduction. The Art of the Novel. New York: Charles Scribner's Sons.

Bourdieu, Pierre. 1977. Outline of Theory of Practice, trans. Richard Nice. Cambridge, UK: Cambridge University Press.

Chan, Winnie. 2007. The Economy of the Short Story in British Periodicals of the 1890s. London: Routledge.

Collier, Patrick. 2011. 'Literary Prestige Is the Eminence of Nobodies': Henry James, Literary Work, and Celebrity in the Illustrated London News. Journal of Modern Periodical Studies 2 (1): 1-32.

Dawson, Janis. 2013. Not for Girls Alone, But for Anyone Who Can Relish Really Good Literature: Meade. Atalanta and the Family Literary Magazine. Victorian Periodicals Review 46 (4) (Winter): 475-498.

Delaney, Paul. 2002. Literature, Money, and the Market from Trollope to Amis. New York: Palgrave.

Dillingham, William B. 2005. Rudyard Kipling: Hell and Heroism. New York: Palgrave Macmillan.

Edel, Leon. 1962. Henry James: The Middle Years. Philadelphia: Lippincott.

Ellard, Virginia G. 1888. How to Write a Story. The Writer 2 (10) (October): 239-241.

English, James. 2008. The Economy of Prestige: Prizes, Awards, and the Circulation of Cultural Value. Cambridge, MA: Harvard University Press.

Gannett, A.M. 1888 How to Write Short Stories. The Writer 2 (10) (October): 239-241.

Hanscom, A.L. 1888. Method Needed in Literary Work. The Writer 2 (4) (April): 247-249.

Head, Dominic. 1992. The Modernist Short Story: A Study in Theory and Practice. Cambridge: Cambridge University Press.

Hills, William H. 1895. The Art of Short-Story Writing. The Writer 8 (4) (April): 48-51.

- 1889. Helpful Hints and Suggestions. The Writer 3 (10) (October): 228.

Hubert, Philip G. 1888. The Filling of Clippings. The Writer 2 (7): 163.

Hunter, Adrian. 2007. The Cambridge Introduction to the Short Story in English. Cambridge: Cambridge University Press.

James, Henry. 1884. The Art of Fiction. Longman's Magazine IV: 502-521.

- 1898. The Story-Teller at Large. Fortnightly Review 69 (April): 650654.

Levy, Andrew. 1993. The Culture and Commerce of the American Short Story: America's Workshop. Cambridge: Cambridge University Press.

Lodge, David. 1996. Creative Writing: Can It/Should It Be Taught? The Practice of Writing. London: Penguin Books. 
Matthews, Brander. 1885. The Philosophy of the Short-Story. Lippincott's, a Popular Journal of General Literature 36 (October): 366-374.

Meade, W.T. 1892-1893. From the Editor's Standpoint. Atalanta VI: 839-842.

Miller, James E. 1972. Theory of Fiction: Henry James. Lincoln: University of Nebraska Press.

Mitchell, Sally. 1995. The New Girls' Culture in England. Columbia: Columbia University Press.

1896. New and Notes. The Writer 10 (4): 59-60.

Noël-Thomas, Francis. 1992. The Writer Writing: Philosophical Acts in Literature Princeton: Princeton University Press.

Norris, W.E. 1892-1893. Style in Fiction. Atalanta VI: 59-63.

Pattee, Fred Lewis. 1923. The Development of the American Short Story: An Historical Survey. New York: Harper and Bros.

Poe, Edgar Allan. 2004. The Philosophy of Composition. The Selected Writings of Edgar Allan Poe, ed. by G.R. Thompson, 675-684. New York: Norton.

1887-1888. Scholarship Competition Questions. Atalanta I: 54.

1892-1893. Scholarship Competition. Atalanta VI: 842.

Scholes, Robert, and Clifford Wulfmann, eds. 2010. Modernism in the Magazines: An Introduction. New Haven: Yale University Press.

Simon, Linda. 2007. The Critical Reception of Henry James: Creating a Master. Rochester: Camden House.

Smith, Janet Adam. 1948. Henry James and Robert Louis Stevenson: A Record of Friendship and Criticism. London: Rupert Hart-Davis.

Spiropoulou, Angeliki. 2015. 'In or about 1922': Virginia Woolf, Katherine Mansfield, and Modern Fiction. 1922: Literature, Culture, Politics, ed. Jean-Michel Rabaté, 74-90. Cambridge: Cambridge University Press.

Stevenson, Robert Louis. 1884. A Humble Remonstrance. Longman's Magazine V (December): 139-47.

1892-1893. Studies in Composition. Atalanta VI: 135.

1892-1893. Studies in Style. Atalanta VI: 63. 
Open Access This chapter is licensed under the terms of the Creative Commons Attribution 4.0 International License (http://creativecommons.org/licenses/ by $/ 4.0 /)$, which permits use, sharing, adaptation, distribution and reproduction in any medium or format, as long as you give appropriate credit to the original author(s) and the source, provide a link to the Creative Commons license and indicate if changes were made.

The images or other third party material in this chapter are included in the chapter's Creative Commons license, unless indicated otherwise in a credit line to the material. If material is not included in the chapter's Creative Commons license and your intended use is not permitted by statutory regulation or exceeds the permitted use, you will need to obtain permission directly from the copyright holder.

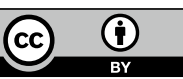

